\title{
STRATEGI PENGEMBANGAN AYAM RAS PETELUR DI KOTA SAMARINDA KALIMANTAN TIMUR
}

\section{DEVELOPMENT STRATEGY OF LAYER IN SAMARINDA CITY EAST KALIMANTAN}

\author{
Herdianto Kurniawan*, Budi Guntoro, dan Wihandoyo \\ Fakultas Peternakan, Universitas Gadjah Mada, Jl. Fauna No. 3, Bulaksumur, Yogyakarta, 55281
}

\section{INTISARI}

Penelitian ini bertujuan untuk mengidentifikasi dan menganalisis kekuatan, kelemahan, peluang dan ancaman yang dihadapi kota Samarinda dalam pemenuhan telur ayam ras sekaligus untuk merumuskan strategi yang terbaik dan cocok bagi daerah untuk menghadapi kekurangan pasokan telur ayam ras. Penelitian ini dilaksanakan pada bulan November 2009. Metode yang digunakan dalam yaitu metode analisis deskriptif. Metode pengumpulan data dilakukan dengan menggunakan kuesioner, wawancara, observasi dan studi literatur. Analisis data menggunakan analisis SWOT (strengths, weaknesses, opportunities, threats) yang dipakai untuk mengidentifikasi faktor lingkungan internal (kekuatan dan kelemahan) dan faktor lingkungan eksternal (peluang dan ancaman) daerah. Hasil analisis kemudian digambarkan dalam kuadran SWOT dan diinterpretasikan pada matriks SWOT sehingga bisa diperlihatkan posisi dan arah perkembangan daerah serta alternatif strategi yang bisa dijalankan. Berdasarkan hasil penelitian menunjukkan bahwa kota Samarinda mempunyai nilai identifikasi terhadap faktor internal sebesar 0,3922, sedangkan nilai identifikasi terhadap faktor eksternal diperoleh angka 0,0308. Strategi dalam pengembangan ayam ras petelur di kota Samarinda dilakukan dengan cara strategi pertumbuhan agresif (growth oriented strategy) pada kuadran I dengan kekuatan lebih besar dari pada peluang, sehingga daerah harus bisa menggunakan kekuatan tersebut dengan memanfaatkan peluang yang ada.

(Kata kunci: Ayam ras petelur, Strategi pengembangan, Analisis SWOT)

\begin{abstract}
The study was aimed to identify and to analyze the strengths, weaknesses, opportunities and threats that faced the city of Samarinda in fulfilling the egg need and to formulate the best and suitable strategy for the region to face the shortage of egg supply. The study was conducted in November 2009. The method used in the study was descriptive analysis method. Methods of data collection using questionnaires, interviews, observation and literature study. Methods of data analysis using the SWOT analysis (strengths, weaknesses, opportunities, threats) were used to identify the internal environmental factors (strengths and weaknesses) and external environmental factors (opportunities and threats) areas. The result was then drawn in the quadrant analysis of SWOT and interpreted in the SWOT matrix could be to show the position and direction of regional development as well as alternative strategies that can be run. The results showed that internal identified value was 0.3922 and the external identified value was 0.0308 . Development strategy at Samarinda in the first quadrant with a strengths was greater than the opportunities, so the region must be able to use these strengths to take advantage of existing opportunities. The area should implement an aggressive growth strategy (growth oriented strategy) in order to meet the self need of eggs in the region Samarinda.
\end{abstract}

(Key word: Layer, Development strategy, SWOT analysis)

\section{Pendahuluan}

Pengembangan peternakan di kota Samarinda hingga saat ini belum memberikan hasil yang optimal (Anonimus, 2009 ${ }^{\mathrm{a}}$ ). Pengembangan peternakan masih memerlukan penanganan yang serius menuju peternakan yang modern. Salah satu permasalahan yang dihadapi daerah yaitu belum terpenuhinya kebutuhan konsumsi telur ayam ras masyarakat $(4,04 \mathrm{~kg} / \mathrm{kapita} / \mathrm{tahun})$ sesuai dengan standar yang ditetapkan yaitu $6,5 \mathrm{~kg} / \mathrm{kapita} / \mathrm{tahun}$ (Anonimus, 2009 ${ }^{\mathrm{b}}$ ).

Sektor peternakan sebagai salah satu kegiatan ekonomi masyarakat, perlu dikaji secara kuantitatif seberapa besar sektor peternakan ayam petelur berperan dalam mendukung pengembangan kota

\footnotetext{
* Korespondensi (corresponding author):

Telp. +62 81328422728

E-mail: herdianto700@gmail.com
} 
Samarinda yang pada akhirnya diharapkan bisa menjadi penentu dalam kebijakan pengembangan kota Samarinda. Dengan mempertimbangkan faktor-faktor strategis maka perlu dilakukan suatu perencanaan strategis yang terukur dan terarah dalam menentukan pengembangan peternakan ayam petelur di kota Samarinda. Kekuatan, kelemahan, peluang, dan ancaman yang dimiliki kota Samarinda dalam pemenuhan telur ayam ras daerahnya sendiri dan strategi harus ditetapkan Pemerintah Kota Samarinda dalam memanfaatkan segala kekuatan dan peluang serta kelemahan dan tantangan dalam pengembangan ayam petelur. Tujuan dari penelitian ini adalah menganalisis faktor-faktor kekuatan, kelemahan, peluang, dan ancaman dalam pengembangan ayam petelur dalam memenuhi kebutuhan telur ayam ras di Samarinda sekaligus memformulasikan alternatif strategi pengembangan ayam petelur sesuai dengan kondisi saat ini.

\section{Materi dan Metode}

Penelitian dilakukan di wilayah Dinas Perikanan dan Peternakan Kota Samarinda dengan dengan responden yang terdiri dari: staff dan jajaran bidang peternakan, dosen dan mahasiswa Universitas Mulawarwan, praktisi dan peternak. Desain yang digunakan dalam penelitian ini adalah penelitian deskriptif. Pengumpulan data selama penelitian dilakukan dengan menggunakan metode sensus untuk responden peternak dan kuesioner sebagai alat pengumpul data (Singarimbun dan Effendi, 1989). Responden dari Dinas PerikananPeternakan, responden mahasiswa dan Dosen Universitas Mulawarman ditentukan dengan metode pengambilan sampel bertujuan (purposive sampling) (Sugiyono, 2007). Jumlah responden akan tersebar pada lingkup Dinas Perikanan dan Peternakan 5 orang yang menempati masing-masing kepala seksi, mahasiswa peternakan tingkat akhir Universitas Mulawarman 20 orang, Dosen Peternakan Universitas Mulawarman 5 orang, 4 praktisi, dan 5 peternak.

Analisis data dilakukan dengan menggunakan SWOT analisis terhadap lingkungan internal (kekuatan dan kelemahan) dan lingkungan eksternal (peluang dan ancaman) (Rangkuti, 2002 cit. Syamsu, 2009). Hasil identifikas faktor-faktor selanjutnya diberi bobot dan peringkat. Nilai bobot dikalikan dengan nilai peringkatnya untuk mendapatkan skor (nilai tertimbang) untuk semua faktor penentu (Rangkuti, 2008).

\section{Hasil dan Pembahasan}

Pengembangan sub sektor peternakan memiliki posisi yang cukup penting dalam mewujudkan swasembada protein di kota Samarinda karena peternakan ayam ras petelur merupakan salah satu penyedia protein terbesar setelah daging ayam ras. Pada tahun 2008 kontribusi sektor pertanian yang di dalamnya terdapat sub sektor peternakan dan hasilhasilnya mampu memberikan kontribusi pendapatan daerah regional bruto (PDRB) sebesar 2,20\%. Untuk itu perlu dilakukan identifikasi dan evaluasi untuk menentukan strategi dalam pengembangan ayam ras petelur di kota Samarinda.

\section{Lingkungan internal}

Tempat pemasaran yang strategis dan selera konsumen yang tinggi terhadap telur lokal merupakan kekuatan yang mendapat perhatian penting dalam pengembangan ayam ras petelur

Tabel 1. Hasil identifikasi faktor kekuatan pengembangan ayam ras petelur di kota Samarinda (results of strength factors identification for layer development in Samarinda)

\begin{tabular}{clccc}
\hline \hline No & \multicolumn{1}{c}{ Indikator kekuatan (strength indicator) } & $\begin{array}{c}\text { Bobot } \\
\text { (value) }\end{array}$ & $\begin{array}{c}\text { Skor } \\
\text { (scores) }\end{array}$ & $\begin{array}{c}\text { Skor total } \\
\text { (total score) }\end{array}$ \\
\hline 1 & $\begin{array}{l}\text { Luasnya areal yang potensial untuk pengembangan peternakan } \\
\text { ayam ras petelur di kota Samarinda (the area of potential for the } \\
\text { development of layer farms in Samarinda) }\end{array}$ & 0,202 & 4,462 & 0,9012 \\
2 & $\begin{array}{l}\text { Adanya keinginan yang kuat dari pemerintah daerah untuk } \\
\text { meningkatkan hasil produksi peternakan (the existence of a strong } \\
\text { desire of local governments to increase livestock production) }\end{array}$ & 0,185 & 3,885 & 0,7187 \\
3 & $\begin{array}{l}\text { Akses jalan yang mudah dari dan ke daerah peternakan dan } \\
\text { pemasaran (easy access to and from farms and marketing) }\end{array}$ & 0,193 & 3,846 & 0,7423 \\
4 & $\begin{array}{l}\text { Kota Samarinda merupakan ibukota provinsi sehingga kegiatan } \\
\text { pemasaran sangat strategis (Samarinda is the capital of the } \\
\text { province so very strategic marketing activities) }\end{array}$ & 4,210 & 0,8965 \\
5 & $\begin{array}{l}\text { Selera konsumen yang tinggi untuk membeli telur ayam ras } \\
\text { peternak lokal (high consumer appetite for buying local breeder } \\
\text { eggs) }\end{array}$ & 0,210 & 4,308 & 0,9046 \\
\hline & Total & 1,000 & 4,1633 \\
\hline
\end{tabular}


berdasarkan bobot terbesar. Telur lokal dinilai masyarakat memiliki kualitas yang lebih bagus dari pada telur yang berasal dari luar daerah seperti Sulawesi dan Surabaya. Telur ayam lokal yang dimaksud yaitu telur ayam ras yang dihasilkan dari peternak setempat.

Faktor kelemahan dalam pengembangan ayam ras petelur di kota Samarinda yaitu belum tersedianya sarana listrik yang memadai sampai ke lokasi peternakan (farm), terbatasnya sumber daya manusia peternakan seperti petugas kesehatan dan penyuluh lapangan. Sarana listrik yang masih belum memadai mengharuskan peternak mencari alternatif sumber listrik seperti generator listrik (genset). Air sebagai sumber air juga harus di ambil dari danau atau rawa di sekitar farm.

Hasil perhitungan dari nilai tertimbang faktor lingkungan internal (kekuatan dan kelemahan) dapat diperoleh nilai sebesar 0,3922. Besarnya nilai tersebut diperoleh dari hasil pengurangan antara nilai tertimbang faktor kekuatan dikurangi dengan nilai tertimbang faktor kelemahan. Dalam hal ini nilai yang dimaksud yaitu 4,1633 - 3,7712= 0,3922. Nilai tersebut akan digunakan sebagai nilai sumbu X (sumbu horizontal) dalam gambar diagram SWOT.

\section{Lingkungan eksternal}

Analisis faktor lingkungan eksternal diharapkan dapat mengidentifikasi peluang dan ancaman dalam menentukan strategi pengembangan ayam ras petelur di kota Samarinda. Hasil identifikasi terhadap faktor peluang dalam pengembangan ayam ras petelur di kota Samarinda memiliki bobot antara 0,223 sampai dengan 0,170 yang ditunjukkan dalam Tabel 3.

Peluang terbesar atau yang memiliki nilai bobot tertinggi yaitu permintaan komoditas peternakan khususnya telur seiring dengan bertambahnya jumlah penduduk (Anonimus, 2010). Tabel 4 menunjukkan bahwa dalam kurun waktu empat tahun terakhir konsumsi masyarakat terhadap komoditi bahan makanan protein (telur dan susu) meningkat dari tahun ke tahun. Peluang selanjutnya yang dapat diambil yaitu adanya otonomi daerah dan perkembangan informasi-teknologi. Otonomi daerah membuat daerah dapat mengatur daerahnya sendiri sesuai dengan kondisi wilayah masingmasing daerah.

Faktor penting yang teridentifikasi dengan nilai bobot dan rating terendah yaitu kebebasan dalam pengelolaan sumber daya alam (SDA). Kebebasan yang dimaksud adalah kebebasan daerah dalam melaksanakan pemerintahan dalam rangka mengembangkan kearifan lokal seperti pengembangan plasma nutfah ayam Nunukan. Adanya rencana pengembangan ini maka perkembangan unggas khususnya ayam ras petelur juga ikut terjaga kelangsungan produksinya seperti kesungguhan penggunaan lahan untuk produksi jagung.

Salah satu ancaman yang perlu mendapatkan perhatian utama dengan memiliki nilai bobot dan

Tabel 2. Hasil identifikasi faktor kelemahan pengembangan ayam ras petelur di kota Samarinda (results of weakness factors identification for layer development in Samarinda)

\begin{tabular}{|c|c|c|c|c|}
\hline No & Indikator kelemahan (weaknesses indicators) & $\begin{array}{l}\text { Bobot } \\
\text { (value) }\end{array}$ & $\begin{array}{c}\text { Skor } \\
\text { (scores) }\end{array}$ & $\begin{array}{c}\text { Skor total } \\
\text { (total score) }\end{array}$ \\
\hline 1 & $\begin{array}{l}\text { Tingkat pengetahuan dan pemanfaatan teknologi tepat guna oleh } \\
\text { petani peternak sangat terbatas (the level of knowledge and } \\
\text { utilization of appropriate technologies by farmers ranchers are } \\
\text { very limited) }\end{array}$ & 0,194 & 3,885 & 0,7536 \\
\hline 2 & $\begin{array}{l}\text { Terbatasnya sumber daya manusia (SDM) peternakan (pegawai dan } \\
\text { petugas lapangan) (limited human resources ranch (staff and field } \\
\text { workers)) }\end{array}$ & 0,204 & 4,000 & 0,8160 \\
\hline 3 & $\begin{array}{l}\text { Belum tersedianya air bersih dan listrik yang memadai sampai ke } \\
\text { peternakan (lack of clean water and adequate electricity to the } \\
\text { ranch) }\end{array}$ & 0,204 & 3,308 & 0,7768 \\
\hline 4 & $\begin{array}{l}\text { Sistem pemeliharaan ternak sebagian besar belum komersial dan } \\
\text { usaha sambilan (maintenance system largely unaware of the } \\
\text { commercial livestock and sideline business) }\end{array}$ & 0,204 & 3,692 & 0,7532 \\
\hline \multirow[t]{2}{*}{5} & $\begin{array}{l}\text { Terbatasnya sarana dan prasarana dalam pengembangan usaha } \\
\text { produksi dan pemasaran (angkutan: truk, perahu, alat komunikasi: } \\
\text { HP, telefon, dll.) (limited facilities and infrastructure in the } \\
\text { development of production and marketing (transport: trucks, boats, } \\
\text { communications equipment: HP, telephone, etc.)) }\end{array}$ & 0,194 & 3,462 & 0,6715 \\
\hline & Total & 1,000 & & 3,7712 \\
\hline
\end{tabular}


Tabel 3. Hasil identifikasi faktor peluang pengembangan ayam ras petelur di kota Samarinda (results of opportunities factors identification for layer development in Samarinda)

\begin{tabular}{|c|c|c|c|c|}
\hline No & Indikator peluang (indicators of opportunity) & $\begin{array}{c}\text { Bobot } \\
\text { (value) }\end{array}$ & $\begin{array}{c}\text { Skor } \\
\text { (scores) }\end{array}$ & $\begin{array}{c}\text { Skor total } \\
\text { (total score) }\end{array}$ \\
\hline 1 & $\begin{array}{l}\text { Adanya otonomi daerah membuat pemda dapat mengatur dirinya } \\
\text { sendiri (regional autonomy to make local governments can regulate } \\
\text { themselves) }\end{array}$ & 0,205 & 3,731 & 0,7648 \\
\hline 2 & $\begin{array}{l}\text { Kebebasan dalam pengelolaan sumber daya alam hubungannya } \\
\text { dengan kearifan lokal (freedom in the management of natural } \\
\text { resources relationship with local wisdom) }\end{array}$ & 0,170 & 3,846 & 0,6538 \\
\hline 3 & $\begin{array}{l}\text { Era globalisasi dan perdagangan bebas sehingga daerah bebas } \\
\text { mempromosikan daerahnya untuk menarik investor dan kerjasama } \\
\text { dalam pengelolaan sumber daya peternakan (the era of } \\
\text { globalization and free trade area so freely promote their region to } \\
\text { attract investors and cooperation in livestock resources) }\end{array}$ & 0,196 & 3,769 & 0,7388 \\
\hline 4 & $\begin{array}{l}\text { Permintaan komoditas peternakan mengalami peningkatan seiring } \\
\text { dengan bertambahnya jumlah penduduk dan tingkat pendapatan } \\
\text { (request for farm commodities have increased in line with the } \\
\text { increase of population and income levels) }\end{array}$ & 0,223 & 4,385 & 0,9778 \\
\hline \multirow[t]{2}{*}{5} & $\begin{array}{l}\text { Perkembangan teknologi dan informasi (the development of } \\
\text { technology and information) }\end{array}$ & 0,205 & 4,038 & 0,8279 \\
\hline & Total & 1,000 & & 3,931 \\
\hline
\end{tabular}

Tabel 4. Pengeluaran rerata per kapita per bulan menurut kelompok barang (average per capita monthly by groups of commodity)

\begin{tabular}{|c|c|c|c|c|}
\hline Kelompok barang (products) & $2006(\%)$ & $2007(\%)$ & $2008(\%)$ & $2009(\%)$ \\
\hline \multicolumn{5}{|l|}{ Makanan (food) } \\
\hline Padi-padian (grains) & 11,37 & 10,15 & 9,57 & 8,86 \\
\hline Umbi-umbian (tubers) & 0,59 & 0,56 & 0,53 & 0,51 \\
\hline Ikan (fish) & 4,72 & 3,91 & 3,96 & 4,29 \\
\hline Daging (meat) & 1,85 & 1,95 & 1,84 & 1,89 \\
\hline Telur dan susu (eggs and milk) & 2,96 & 2,97 & 3,12 & 3,27 \\
\hline Sayur-sayuran (vegetables) & 4,42 & 3,87 & 4,02 & 3,91 \\
\hline Kacang-kacangan (nuts) & 1,63 & 1,47 & 1,55 & 1,57 \\
\hline Buah-buahan (fruits) & 2,10 & 2,56 & 2,27 & 2,05 \\
\hline Minyak dan lemak (oils and fats) & 1,97 & 1,69 & 2,16 & 1,96 \\
\hline Bahan minuman (beverage ingredients) & 2,50 & 2,21 & 2,13 & 2,02 \\
\hline Bumbu-bumbuan (spices) & 1,37 & 1,1 & 1,12 & 1,08 \\
\hline Konsumsi lainnya (other consumption) & 1,27 & 1,34 & 1,39 & 1,33 \\
\hline Makanan jadi (delicatessen) & 10,29 & 10,48 & 11,44 & 12,63 \\
\hline Minuman beralkohol (aperitif) & - & & - & - \\
\hline Tembakau dan sirih (tobacco and betel) & 5,97 & 4,97 & 5,08 & 5,26 \\
\hline Jumlah (total) & 53,01 & 49,24 & 50,17 & 50,62 \\
\hline \multicolumn{5}{|l|}{ Bukan makanan (non food) } \\
\hline $\begin{array}{l}\text { Perumahan dan fasilitas rumah tangga (housing and } \\
\text { household facilities) }\end{array}$ & 22,56 & 20,78 & 20,21 & 19,89 \\
\hline Barang dan jasa (goods and services) & 14,99 & 17,01 & 17,12 & 17,49 \\
\hline $\begin{array}{l}\text { Pakaian, alas kaki dan tutup kepala (clothing, } \\
\text { footwear and headgear) }\end{array}$ & 4,42 & 3,33 & 3,37 & 3,33 \\
\hline Barang-barang tahan lama (durable goods) & 2,98 & 6,47 & 6,37 & 5,88 \\
\hline Pajak dan asuransi (taxes and insurance) & 0,97 & 1,27 & 1,25 & 1,41 \\
\hline \multirow{2}{*}{$\begin{array}{l}\text { Keperluan pesta dan upacara (feast and ceremonial } \\
\text { purposes) }\end{array}$} & 1,06 & 1,89 & 1,51 & 1,36 \\
\hline & 46,99 & $\mathbf{5 0 , 7 6}$ & 49,83 & 49,38 \\
\hline
\end{tabular}

Sumber: Anonimus, 2010. 
rating tertinggi yaitu insfrastruktur pendukung peternakan seperti pabrik pakan ternak dan penetasan yang belum ada sehingga kontinuitas sarana produksi ternak (sapronak) kurang terjamin.

Dilihat dari potensi luasan wilayahnya, sebenarnya Samarinda dapat menggunakan lahan belum terpakai seluas 9.558 hektar untuk dijadikan lahan perkebunan jagung, melihat selama ini jagung masih harus banyak didatangkan dari Sulawesi. Akibat dari belum dipenuhinya jagung dalam daerah menyebabkan peternak harus membeli pakan jadi yang harganya terhitung mahal. Ada juga peternak yang sudah menerapkan sistem pencampuran pakan sendiri yaitu dengan mencampur pakan jadi dengan sebagian pakan buatan sendiri.

Berdasarkan hasil perhitungan dari besarnya nilai tertimbang, besar nilai dari faktor internal (kekuatan dan kelemahan) diperoleh nilai 0,3922, hasil penguranan nilai tertimbang faktor kekuatan dan kelemahan. Nilai faktor eksternal (peluang dan ancaman) dalam strategi pengembangan ayam ras petelur di kota Samarinda diperoleh nilai 0,0308. Nilai tersebut merupakan hasil pengurangan nilai tertimbang antara faktor peluang dengan faktor ancaman $(3,9631-3,923=0,0308)$. Berdasarkan perhitungan faktor internal dan eksternal tersebut dapat digambarkan menjadi diagram SWOT pada Gambar 1.

Posisi strategi pengembangan ayam ras petelur di kota Samarinda pada pemetaan analisis lingkungan strategik (lingkungan internal dan eksternal) berada pada kuadran I (pertama). Posisi ini dapat menggambarkan secara jelas peluang dan ancaman yang dihadapi dapat disesuaikan dengan

Tabel 5. Hasil identifikasi faktor ancaman pengembangan ayam ras petelur di kota Samarinda (results of threat factors identification for layer development in Samarinda)

\begin{tabular}{|c|c|c|c|c|}
\hline No & Indikator ancaman (threat indicators) & $\begin{array}{l}\text { Bobot } \\
\text { (value) }\end{array}$ & $\begin{array}{c}\text { Skor } \\
\text { (scores) }\end{array}$ & $\begin{array}{c}\text { Skor total } \\
\text { (total score) }\end{array}$ \\
\hline 1 & $\begin{array}{l}\text { Insfrastruktur (pabrik pakan, penetasan) pendukung peternakan } \\
\text { kurang memadai sehingga kurang menjamin ketersediaaan } \\
\text { kontinuitas sapronak dan produk, sehingga menyebabkan biaya dan } \\
\text { harga yang tinggi (poultry infrastructures were insufficient to } \\
\text { support the continuity of resources and product availability, so that } \\
\text { the cost production and product price were high) }\end{array}$ & 0,220 & 4,269 & 0,9392 \\
\hline 2 & $\begin{array}{l}\text { Rendahnya motivasi kerja masyarakat di bidang pertanian } \\
\text { khususnya peternakan (working motivation of farmers were low) }\end{array}$ & 0,180 & 4,077 & 0,7338 \\
\hline 3 & $\begin{array}{l}\text { Pelaksanaan pasar bebas (globalisasi) dan persaingan dari luar } \\
\text { daerah (the implementation of free trade and competition with } \\
\text { external institution) }\end{array}$ & 0,180 & 3,808 & 0,6854 \\
\hline 4 & $\begin{array}{l}\text { Akes peminjaman modal sulit diperoleh sehingga menyebabkan } \\
\text { kesulitan dalam memperoleh modal usaha (the lack of bank loan } \\
\text { acces) }\end{array}$ & 0,220 & 3,654 & 0,8038 \\
\hline \multirow[t]{2}{*}{5} & $\begin{array}{l}\text { Belum terciptanya kerjasama dan pola kemitraan dalam proses } \\
\text { produksi (penyediaan sapronak) (cooperation and partnership in } \\
\text { production hasn't exist yet) }\end{array}$ & 0,220 & 3,500 & 0,7700 \\
\hline & Total & 1,000 & & 3,9323 \\
\hline
\end{tabular}

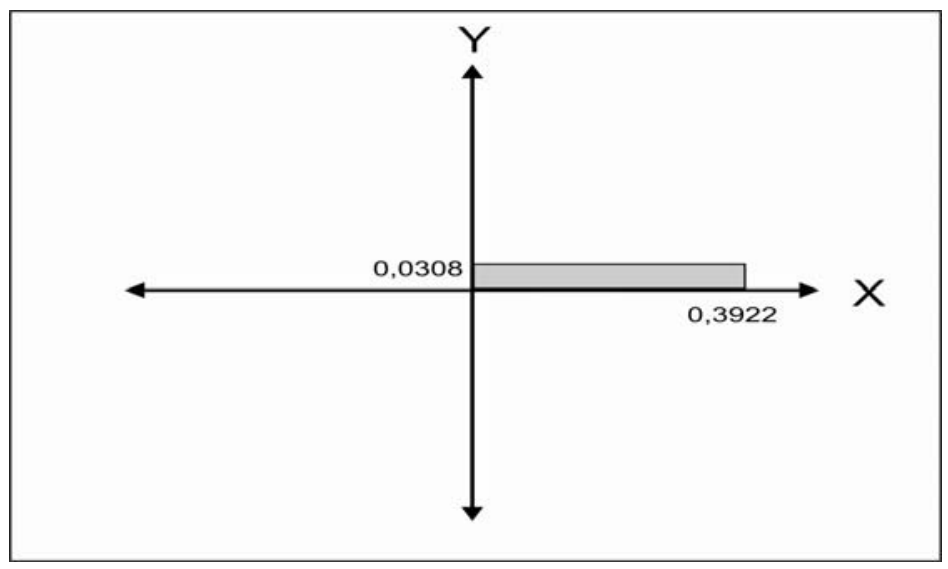

Gambar 1. Diagram strengths, weaknesses, opportunities, dan threats (strengths, weaknesses, opportunities, and threats diagram). 
Tabel 6. Matriks analisis alternatif strategi faktor internal dan faktor eksternal (internal factor alternative strategy and external factor alternative strategy matrix)

\begin{tabular}{|c|c|c|}
\hline IF & \begin{tabular}{l}
\multicolumn{1}{c}{ Kekuatan } \\
Luas areal masih potensial \\
Keinginan kuat pemerintah utk \\
peningkatan produksi peternakan \\
Akses jalan yang mudah \\
Kegiatan pemasaran strategis \\
Selera konsumen tinggi terhadap \\
telur peternak lokal
\end{tabular} & $\begin{array}{l}\text { Kelemahan } \\
\text { Tingkat pengetahuan dan pe- } \\
\text { manfaatan teknologi tepat guna } \\
\text { msh rendah } \\
\text { SDM peternak dan petugas terbatas } \\
\text { Air bersih dan listrik belum cukup } \\
\text { Pemeliharaan belum komersial } \\
\text { Sarana prasarana usaha terbatas }\end{array}$ \\
\hline $\begin{array}{l}\text { Peluang } \\
\text { Otonomi daerah } \\
\text { Kebebasan pengelolaan SDA } \\
\text { Kebebasan menarik investor } \\
\text { Permintaan telur meningkat } \\
\text { sejalan dengan jumlah penduduk } \\
\text { Perkembangan teknologi in- } \\
\text { formasi }\end{array}$ & $\begin{array}{lcr}\text { Menciptakan } & \text { strategi dengan } \\
\text { menggunakan } & \text { kekuatan untuk } \\
\text { memanfaatkan } & \text { peluang yang ada } \\
\text { yaitu dengan } 5 \text { strategi pen-dekatan }\end{array}$ & $\begin{array}{l}\text { 1. Meningkatkan kualitas sumber } \\
\text { daya peternakan melalui } \\
\text { pendampingan dan pembinaan } \\
\text { 2. Menciptakan kawasan } \\
\text { khusus/tata ruang }\end{array}$ \\
\hline $\begin{array}{l}\text { Ancaman } \\
\text { Pabrik pakan yang belum ada } \\
\text { Rendahnya motivasi kerja bidang } \\
\text { peternakan } \\
\text { Persaingan dengan luar daerah } \\
\text { Modal usaha sulit karena suku } \\
\text { bunga tinggi } \\
\text { Belum tercipta pola kemitraan }\end{array}$ & 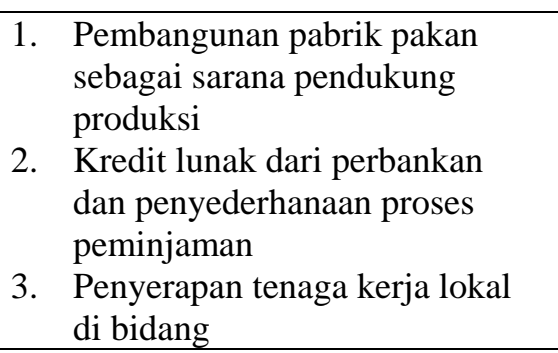 & $\begin{array}{l}\text { 1. Dilakukan kerja sama atau pola } \\
\text { kemitraan antara pihak swasta, } \\
\text { pemerintah dan akademisi } \\
\text { (Perguruan Tinggi) } \\
\text { 2. Saling bekerja sama antara } \\
\text { sektor peternakan dengan } \\
\text { sektor lain yang terkait }\end{array}$ \\
\hline
\end{tabular}

kekuatan dan kelemahan yang dimiliki. Posisi strategis juga memberikan petunjuk bahwa kekuatan yang dimiliki lebih besar dari kelemahan yang ada sehingga stretegi yang dipakai adalah menggunakan kekuatan yang dimiliki untuk memanfaatkan peluang yang ada.

Dengan demikian, rumusan strategi yang sebaiknya digunakan oleh Dinas Perikanan dan Peternakan adalah mendukung kebijakan pertumbuhan yang agresif. Strategi pertumbuhan agresif (growth oriented strategy) yaitu menggunakan kekuatan yang ada untuk memanfaatkan peluang yang ada. Strenght opportunities strategy atau strategi SO merupakan istilah yang biasa digunakan dalam perumusan strategi ini.

Alternatif strategi pendekatan yang digunakan adalah: a) Membangun usaha yang mampu menyediakan kebutuhan pakan ternak dengan penyerapan tenaga kerja local; b) Dukungan permodalan dari pihak pemerintah atau swasta bagi pengembangan usaha pakan ternak; c) Usaha budidaya tanaman jagung yang diarahkan untuk memenuhi kebutuhan bahan baku lokal pakan ternak; d) Pembangunan pergudangan baik sebagai gudang pakan ternak maupun sebagai gudang penyimpanan bahan baku yang memadai; e) Memperlancar arus perdagangan melalui penyediaan sarana transportasi (jalan) yang memadai. Pendekatan strategis tersebut merupakan suatu pilihan dengan tetap memper- hatikan faktor lingkungan internal yang dimiliki dan faktor lingkungan eksternal yang dihadapi.

\section{Kesimpulan dan Saran}

\section{Kesimpulan}

Dari penelitian ini dapat disimpulkan bahwa identifikasi terhadap faktor-faktor internal diperoleh angka 0,3922, sedangkan identifikasi terhadap faktor-faktor eksternal diperoleh angka 0,0308. Strategi dalam pengembangan ayam ras petelur di kota Samarinda dilakukan dengan cara strategi pertumbuhan agresif (kuadran pertama).

\section{Saran}

Dalam rangka mengembangkan ayam ras petelur di kota Samarinda diharapkan Dinas Perikanan dan Peternakan setempat memberikan kemudahan akses dalam memperoleh tambahan modal usaha (kredit) lunak dan prosedur peminjaman, selain itu perlu adanya kebijakan yang tegas dari Pemerintah Kota untuk membangun pola kemitraan dalam usaha peternakan ayam ras petelur.

\section{Daftar Pustaka}

Anonimus. 2009a . Bappeda Samarinda 2009. Potensi Pengembangan Daerah Kota Samarinda. Available at http://www.bappeda- 
samarinda.go.id. Accession date: 10 Oktober 2009.

Anonimus. 2009 . Samarinda dalam Angka 2009. Available at http://bappeda.samarinda.go.id/ search.php?cx=005190682209931954082\%3 Ad7jgqoxue0y\&cof=FORID\%3A10\&ie=UT F8\&q=samarinda+dalam+angka $+2009 \& s a=S$ earch\&siteurl=www.bappeda.samarinda.go.id \%2Fsda.php\#1073. Accession date: 28 Februari 2010.

Anonimus. 2010. Statistik Indonesia. Badan Pusat Statistik 2010. Jakarta.
Rangkuti, F. 2008. Analisis SWOT Teknik Membedah Kasus Bisnis. Reorientasi Konsep Perencanaan Strategis untuk Menghadapi Abad 21. Cetakan ke-15. Gramedia Pustaka Utama: Jakarta.

Singarimbun, M. dan S. Efendi. 1989. Metode Penelitian Survai. LP3ES. Jakarta.

Sugiyono. 2007. Statistika untuk Penelitian. Cetakan ke-12. Revisi terbaru. Alfabeta, Bandung.

Syamsu, J.A. 2009. Analisis Perumusan Strategi. Fakultas Peternakan Universitas Hasanudin: Makasar. Available at http://jasmal. blogspot.com/. Accession date: 16 Desember 2009. 